\title{
YOUR HONOR, ON SOCIAL MEDIA: THE JUDICIAL ETHICS OF BOTS AND BUBBLES
}

\author{
Katrina Lee*
}

TABLE OF CONTENTS

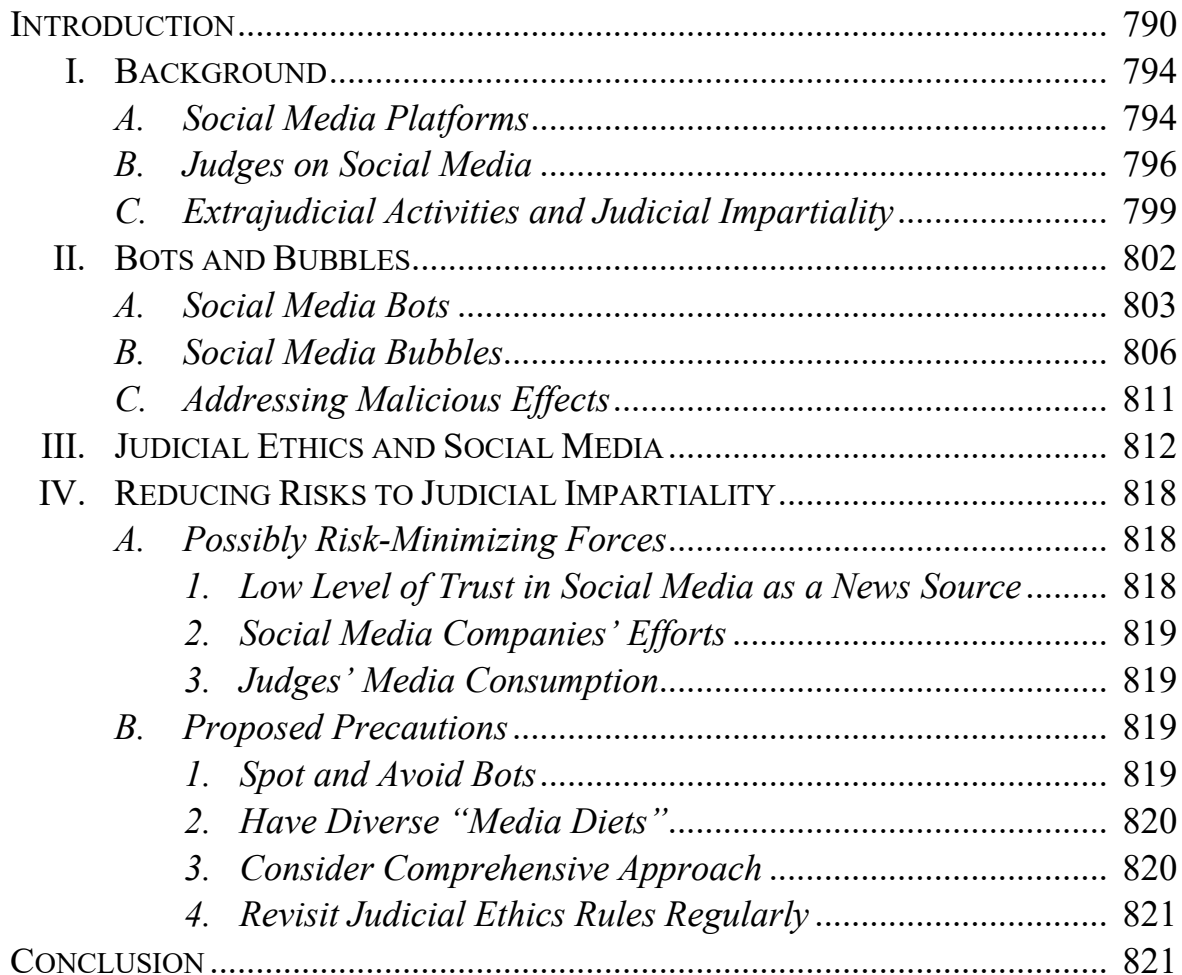

* Katrina Lee, Clinical Professor of Law at The Ohio State University Moritz College of Law, can be found on Twitter at @katrinajunelee. She is grateful to Ryan Calo, Erin Carroll, Alexa Z. Chew, Matt Cooper, Arthur F. Greenbaum, Wendy-Adele Humphrey, Judge Steve Leben, Ellen Murphy, Abigail Perdue, Elizabeth G. Thornburg, and Daniel P. Tokaji for their wisdom and comments and to the Moritz College of Law for research funds support. 


\section{INTRODUCTION}

"Social media is a virtual world that is filled with half bots, half real people .... You can't take any tweet at face value. And not everything is what it seems."-Rami Essaid, founder of Distil Networks ${ }^{1}$

In 2017, more than three billion people logged on to social media networks. ${ }^{2}$ Increasingly, judges sitting in county, state, and federal courts in the United States have joined the ranks of social media users. Judges post on social media. They engage followers on Twitter and friends on Facebook. Like other humans using social media, judges may unwittingly encounter bots simulating human behavior or "bubbles" created by algorithms.

This article is the first to examine at length the potential threat to judicial impartiality arising from judges interacting with bots and bubbles-both present, known phenomena on social media. While much scholarly literature has delved into ethical issues implicated by judges' social media contacts, very little attention has been focused on the impact of automated bots and algorithmic bubbles on judges' impartiality. ${ }^{3}$ This article is an effort to begin addressing that literature gap.

1 Nicholas Confessore et al., The Follower Factory, N.Y. TIMES (Jan. 27, 2018), https://ww w.nytimes.com/interactive/2018/01/27/technology/social-media-bots.html [https://perma.cc/ 8DKW-MDBF].

${ }^{2}$ Id.; see also Evan Osnos, Can Mark Zuckerberg Fix Facebook Before It Breaks Democracy?, New Yorker (Sept. 17, 2018), https://www.newyorker.com/magazine/2018/09/17/canmark-zuckerberg-fix-facebook-before-it-breaks-democracy [https://perma.cc/HK6Y-5SM4] ("If Facebook were a country, it would have the largest population on earth. More than 2.2 billion people, about a third of humanity, $\log$ in at least once a month. That user base has no precedent in the history of American enterprise.").

3 See, e.g., Nichola A. Boothe-Perry, Friends of Justice: Does Social Media Impact the Public Perception of the Justice System?, 35 PACE L. ReV. 72, 92 (2014) (stating that without "recognition of the need for guidance and oversight of judge's 'friend'ships to prevent [appearance] of a sense of impropriety[,] the public's perception that unscrupulous or unprofessional behavior has occurred may stir beliefs that justice is not being conducted in a timely, fair or equitable manner, thus undermining the public's confidence in the justice system."); John G. Browning, The Judge as Digital Citizen: Pros, Cons, and Ethical Limitations on Judicial Use of New Media, 8 FAULKNER L. ReV. 131, 154 (2016) ("Certainly, judges should exercise caution in using social media, just as they should in more traditional avenues of communication - including no ex parte communications and no independent investigation of a case. But, unless we want them to be philosopher-priests cloistered in their jurisprudential temples, judges need to be connected to society, with their work reflecting accessibility to the citizens they serve."); Hope A. Comisky \& William M. Taylor, Don't Be a Twit: Avoiding the Ethical Pitfalls Facing Lawyers Utilizing Social Media in Three Important ArenasDiscovery, Communications with Judges and Jurors, and Marketing, 20 TEMP. PoL. \& C. R. L. REV. 297, 310-11 (2011) (“'[O]nce two people are 'friends,' they can monitor each other's profiles even though they are not directly communicating with each other .... Social networking sites then pose the risk that an attorney may, intentionally or not, review any postings that inform the attorney about the judge's mood, temperament, or preferences or, of more concern, postings that a judge inappropriately makes about a case . . . [A]t the start of any case in which an attorney appears before a judge whom he has 'friended' or who belongs to the same network as the judge, the attorney and the judge should 'defriend' one anoth- 
Social media bots, automated accounts run by algorithm, can simulate human interaction on social media. ${ }^{4}$ Social media bubbles, online cocoons where users interact primarily with content that confirm their existing conclusions, can arise from user selections or algorithms deployed by social media companies, or both.

In their more malicious forms, bots and bubbles on social media present potentially unprecedented risks not encountered on other types of media, like television or radio. These heightened risks arise from the speed and frequency at which social media networks can spread and amplify falsehoods and echo chamber effects. Bots, not inherently malicious, can be designed to manipulate public opinion and spread falsehoods on social media. ${ }^{5}$ Bubbles can enhance the impact of bots; social media users in bubbles can more easily believe in a false assertion. ${ }^{6}$ In bubbles, users may experience an echo chamber effect and see only information that confirms their opinions and conclusions. ${ }^{7}$ The term "filter bubble" refers to the unique, personalized information created for a user through algorithms that draw from that user's web activity history. ${ }^{8}$ A user's previous internet use - that might include viewing, following links, and purchasing - feed into algorithms that then determine content for that user. ${ }^{9}$ Per-

er."). A notable welcome exception is Professor Elizabeth Thornburg's discussion of bots and "data-driven echo chamber effects" in her recent article about judges on Twitter. Elizabeth Thornburg, Twitter and the \#So-CalledJudge, 71 SMU L. REV. 249, 300, 313 (2018). Professor Thornburg's article focuses on how judges can continue to communicate with the public on Twitter in a constructive way. $I d$. at 306. This article builds from Professor Thornburg's work.

${ }^{4}$ See Confessore et al., supra note 1; Stefan Wojcik et al., Bots in the Twittersphere, PEW RES. CTR. (Apr. 9, 2018), http://www.pewinternet.org/2018/04/09/bots-in-the-twittersphere/ [https://perma.cc/3JYQ-YV6E].

5 Confessore et al., supra note 1; Onur Varol et al., Online Human-Bot Interactions: Detection, Estimation, and Characterization, 11 InT'L AAAI Conf. ON WeB \& Social MEDIA 280, 280 (2017), https://aaai.org/ocs/index.php/ICWSM/ICWSM17/paper/view/15587/14817 [htt ps://perma.cc/DKL8-PCCH]; see also Joanna M. Burkhardt, Social Media Bots: How They Spread Misinformation, AM. LiBRARIES MAG. (Mar. 1, 2018), https://americanlibrariesmagaz ine.org/2018/03/01/social-media-bots/ [https://perma.cc/637J-PT5N] ("People who are unaware that they are interacting with a bot can easily be supplied with false information .... People with a large network of friends are more likely to accept requests from people they don't know. This can make it relatively easy for bots to infiltrate a network of social media users."). Siri on iPhones and Alexa on Amazon Echo devices are bots; people use them to listen to music, make purchases, and check the weather. Judith Shulevitz, Alexa, Should We Trust You?, ATLANTIC (Nov. 2018), https://www.theatlantic.com/magazine/archive/2018/11/ alexa-how-will-you-change-us/570844/. Beyond the scope of this article, privacy concerns raised by use of Alexa, Siri, and other bots have been discussed by other scholars. See, e.g., Margot E. Kaminski et al., Averting Robot Eyes, 76 MD. L. REV. 983, 984 (2017).

6 See Cass R. Sunstein, \#Republic: Divided Democracy in the Age of Social Media 11 (2017) ("Echo chambers can lead people to believe in falsehoods, and it may be difficult or impossible to correct them. Falsehoods take a toll.").

7 See id. at 115-16.

8 Eli PARISER, The Filter Bubble 9 (2011); see also Eytan Bakshy et al., Exposure to Ideologically Diverse News and Opinion on Facebook, 348 SCI. 1130, 1130 (2015).

9 Bakshy et al., supra note 8, at 1130. 
sonalization, by algorithm or by self-selection, can lead to users "eating the equivalent of information junk food" and leave them vulnerable to assertions set out as "facts." 10

Attempts to moderate or eliminate harmful bots and bubble effects are apparently in process but the potential for harm is not going away anytime soon. ${ }^{11}$ Although social media companies have announced efforts to keep in check the use of both bots and filter bubbles, it is unclear how successful those efforts have been. ${ }^{12}$ In recent years, lawmakers have introduced legislation designed to curb the impact of malicious bots. ${ }^{13}$ In California, legislators passed such a bill. ${ }^{14}$ But, nothing yet exists that comes close to eradicating harmful bots and bubbles from social media.

Like other social media users, judges may be interacting with fake social media accounts designed to manipulate public opinion or spread falsehoods or unverified information. Perhaps at the very same time, judges may be caught in a bubble created by social media platform algorithms that make it more difficult for the human user to encounter opinions, ideas, and arguments different than their own. ${ }^{15}$

Meanwhile, judges are expected to be impartial. Impartiality has long been a cornerstone of the judicial role. ${ }^{16}$ The canons of the Code of Judicial Conduct for U.S. Judges and the American Bar Association's ("ABA") Model Rules of

10 The Filter Bubble: What the Internet is Hiding from You, AmAZON.com, https://www.ama zon.com/Filter-Bubble-What-Internet-Hiding-dp-1594203008/dp/1594203008 (last visited Mar. 14, 2019) (hosting a Q\&A with the author).

11 PARISER, supra note 8, at 14-15.

12 See infra Section II.C.

13 See infra Section II.A.

14 See infra Section II.A.

15 Further, any pernicious impact of bubbles and bots may be enhanced by any isolation judges feel after ascending to the bench. See Isaiah M. Zimmerman, Isolation in the Judicial Career, 36 CT. REV. 4, 4 (2000).

16 See Dmitry Bam, Making Appearances Matter: Recusal and the Appearance of Bias, 2011 BYU L. REV. 943, 950 (2011) ("The American legal system is based on a simple and noncontroversial proposition: a fair and neutral judge is essential to the operation of a just legal system.”); Debra Lyn Bassett \& Rex R. Perschbacher, The Elusive Goal of Impartiality, 97 IowA L. REV. 181, 183 (2011) (emphasis added) ("The notion of an impartial trial under the direction of an unbiased judge is a central tenet of our system of justice.") (emphasis added); Charles Gardner Geyh, The Dimensions of Judicial Impartiality, 65 FLA. L. Rev. 493, 498 (2013) ("Impartiality . . . has been a defining feature of the judicial role dating back to antiquity."). 
Judicial Conduct emphasize judicial impartiality. ${ }^{17}$ Judges are subject to restrictions aimed at preserving impartiality. ${ }^{18}$

With social media bots and bubbles that put social media users at greater risk of believing falsehoods and of seeing only what confirms their own beliefs, judicial impartiality, a central feature of the judicial system, may be under threat at a level not encountered in the past. In this article, I argue for increased precautions and awareness to help maintain judicial impartiality in light of the potential unfortunate impact of social media bots and bubbles. ${ }^{19}$

Part I introduces social media platforms and judges' presence on social media. It also provides a basic overview of judicial conduct rules emphasizing impartiality while encouraging "extrajudicial" activities. Part II explains how social media bots and bubbles work, their potential harmful impact, and how their existence and harmful impacts may be limited. Part III discusses the limited breadth of current judicial ethics rules and standards concerning social media use. Part IV will describe possible ways in which malicious effects of social media bots and bubbles are currently mitigated. It will then propose precautions to help maintain judicial impartiality in the presence of social media bots and bubbles. Ultimately, this article offers an outlook on the ethical landscape of judges engaging on social media that is at once deeply skeptical and cautiously hopeful.

17 Canon Two of the Code of Judicial Conduct for U.S. Judges provides that a judge should "act at all times in a manner that promotes public confidence in the integrity and impartiality of the judiciary." Code of Conduct for United States Judges, 2A GUIDE TO JUDICIARY POLICY Canon 2A (Mar. 12, 2019). Canon Two of the ABA Model Rules of Judicial Conduct states, "A judge shall perform the duties of judicial office impartially, competently, and diligently." Model Code of Judicial Conduct Canon 2 (AM. BAR. Ass'N 2011).

18 For example, judges may not initiate or permit ex parte communications concerning a pending matter. Model Code of Judicial Conduct r. 2.9(A) (AM. BAR. Ass'N 2011). Also, judges may not form relationships with persons that would convey an impression that those persons are in a position to influence the judge. $I d$. at r. $2.4(\mathrm{C})$. This article focuses on judges' use of social media and not on judicial clerks' use of social media. However, much of what is discussed in this article would apply to judicial clerks. The Code of Conduct for Judicial Employees provides that judicial employees must "[a]void [i]mpropriety and the [a]ppearance of [i]mpropriety in [a]ll [a]ctivities[.]" Code of Conduct for Judicial Employees, 2A Guide to Judiciary PoliCY $\S 320$ (Aug. 2, 2013). Also, others have provided guidance on ethical and professionalism issues related to judicial clerks' use of social media. See Abigail L. Perdue, The All-Inclusive Guide to Judicial Clerking 149-52, 178 (2017).

19 See Thornburg, supra note 3, at 253 ("[I]n this day and age, when much of America gets its news from social media and those platforms are being used to delegitimize the judiciary, the third branch can ill afford to disengage. Judicial tweeting, within the limits of the ethics rules, should be encouraged rather than shunned."); David Lat, Judges on Twitter: Is This a Problem?, ABOve LAw (Sept. 30, 2014, 2:18 PM), https://abovethelaw.com/2014/09/judgeson-twitter-is-this-a-problem/ [https://perma.cc/NGQ9-LVQ3] ("[J]udges who blog or tweet help improve public understanding of the courts and increase the transparency and accountability of the judicial system. Judges just need to exercise sound judgment — which, of course, is what we pay them to do. So I say: tweet away, Your Honors!"). 


\section{BACKGROUND}

\section{A. Social Media Platforms}

Social media is a prevalent part of human interactions around the world. In the first quarter of 2018, Facebook reported 1.449 billion daily active users and 241 million monthly active users in the U.S. and Canada. ${ }^{20} 68$ percent of adults in the U.S. report being Facebook users. ${ }^{21}$ Facebook is the most-used social media platform in the U.S. ${ }^{22}$ The most commonly used social media platforms include Facebook, Twitter, LinkedIn, YouTube, Instagram, Snapchat, and WhatsApp. ${ }^{23}$

Social media platforms are "forms of electronic communication (such as websites for social networking and microblogging) through which users create online communities to share information, ideas, personal messages, and other content (such as videos)." ${ }^{24}$ People use social media for varied reasons, including keeping in touch with friends and family, publicizing their careers and businesses, connecting with people with similar interests, gathering information

20 Josh Constine, Facebook Beats in Q1 and Boosts Daily User Growth to 1.45B Amidst Backlash, TECHCRUNCH (Apr. 25, 2018), https://techcrunch.com/2018/04/25/facebook-q1-20 18-earnings/ [https://perma.cc/5EUZ-NNVD].

21 Aaron Smith \& Monica Anderson, Pew Research Ctr., Social Media Use in 2018, at 2 (2018), http://assets.pewresearch.org/wp-content/uploads/sites/14/2018/03/01105133/PI_2 018.03.01_Social-Media_FINAL.pdf.

${ }^{22} \mathrm{Id}$.

23 Id.; see generally FACEBOOK, https://www.facebook.com/ [https://perma.cc/4ZMP-S4JE] (last visited Mar. 10, 2019); INSTAGRAM, https://www.instagram.com/ [http://perma.cc/TJW4 -DADM] (last visited Mar. 10, 2019); LINKEDIN, https://www.linkedin.com/ [https://perma.c c/N69M-4FJ5] (last visited Mar. 10, 2019); SNAPCHAT, https://www.snapchat.com/ [https://p erma.cc/XQ7C-9Q6K] (last visited Mar. 10, 2019); TwITTER, https://www.twitter.com/ [http s://perma.cc/7TQQ-DXRF] (last visited Mar. 10, 2019); WhATSAPP, https://www.whatsapp. com/ [https://perma.cc/E8G2-Q9EK] (last visited Mar. 10, 2019); YouTuBE, https://www.yo utube.com/ [https://perma.cc/6GK2-ZQN4] (last visited Mar. 10, 2019). This article will focus primarily on Facebook and Twitter, due to the appearance of judges on them, and the availability of information and studies concerning them.

24 Social Media, MERRIAM-WEBSTER, https://www.merriam-webster.com/dictionary/social\% 20media (last visited Mar. 10, 2019); see also Cynthia Gray, Social Media and Judicial Ethics: Part 1, 39 Jud. Conduct ReP. 2, 2 (2017), https://www.ncsc.org/ /media/Files/PDF/Top ics/Center\%20for\%20Judicial\%20Ethics/JCR/JCR_Spring_2017.ashx [https://perma.cc/X3U Z-ELRY]. ("Social media are web-based services on which individuals share information, ideas, interests, activities, photos, and videos through virtual communities and networks using electronic devices. Types of social media include social and professional networking sites (such as Facebook and LinkedIn), review sites (such as Yelp and TripAdvisor), sites for sharing photos, images, and videos (such as Instagram, YouTube, Pinterest, and Snapchat), blogs, micro-blogs (such as Twitter and Tumblr), information web-sites that allow changes, contributions, or corrections (such as Wikipedia), question-and-answer sites (such as Quora), and discussion groups and threads (such as Reddit)."). 
and news, and airing and challenging political views. ${ }^{25}$ About a quarter of adults in the U.S. get news from two or more social media sites. ${ }^{26}$ Facebook is a common source, with about 45 percent of adults in the U.S. getting news from there. ${ }^{27}$ More than half of adults in the U.S. aged fifty or older report getting news on social media sites. ${ }^{28}$ About 18 percent and 11 percent of adults in the U.S. turn to YouTube or Twitter, respectively, for news. ${ }^{29}$

Not all social media platforms serve the same purpose. For example, Facebook is different than Twitter because Facebook's users are more often people who have ties based on offline social contexts (like family members connected on Facebook) rather than topical interests (like people on Twitter who have an interest in mindfulness and lawyer well-being). ${ }^{30}$

But, in addition to those seemingly harmless uses, social media have also been a platform for crime, terrorism, bullying, death threats, and election manipulation. ${ }^{31}$ In 2012, the New York Times reported that Russian hackers ac-

25 See Aaron Smith, Pew Research Ctr., Why Americans Use Social Media 2 (2011), available at http://www.pewinternet.org/Reports/2011/Why-Americans-Use-Social-Media. aspx; Donna L. Hoffman \& Thomas P. Novak, Why Do People Use Social Media? Empirical Findings and a New Theoretical Framework for Social Media Goal Pursuit 30 tbl.4 (Nat'1 Sci. Found., Grant No. IIS-1114828 Jan. 17, 2012), https://papers.ssrn.com/sol3/paper s.cfm?abstract_id=1989586 [https://perma.cc/GQ2K-QZ6G].

26 Natasha Lomas, Even More US Adults Now Getting News from Social Media, Says Pew, TECHCRUNCH (Sept. 9, 2017), https://techcrunch.com/2017/09/09/even-more-us-adults-nowgetting-news-from-social-media-says-pew/ [http://perma.cc/Q4HB-RXZ3]. Prevalence of use, however, should not be equated with depth of trust or confidence. SMITH \& ANDERSON, supra note 21, at 7. The 2018 Pew study on social media use found that a mere 3 percent of social media users in the United States indicate they have "a lot of trust" in the sites they use. Id.

27 Lomas, supra note 26.

$28 I d$.

29 Id.; Professor Elizabeth Thornburg has discussed how people use Twitter:

An American Press Institute survey in 2015 found that " $81 \%$ [of Twitter users] keep up with the news at least daily" ( $71 \%$ use it several times a day). But they are not merely consumers of information. Thirty one percent say they use Twitter "to tell others what I am doing and thinking about," 24\% "to 'keep in touch with people I know," 19\% "[t]o share news" and "[t]o network," and $18 \%$ "[t]o follow trending topics."

Thornburg, supra note 3, at 256 (alterations in original) (quoting Tom Rosenstiel et al., How People Use Twitter in General, AM. Press InST. (Sept. 1, 2015, 10:30 AM), http://www.ame ricanpressinstitute.org/publications/reports/survey-research/how-people-use-twitter-in-gener $\mathrm{al} /$ ).

30 Bakshy et al., supra note 8, at 1131.

31 See, e.g., Kate Starbird, Examining the Alternative Media Ecosystem Through the Production of Alternative Narratives of Mass Shooting Events on Twitter, U. WASH. (2017), http://fa culty.washington.edu/kstarbi/Alt_Narratives_ICWSM17-CameraReady.pdf. In an interview, Professor Starbird commented:

Your brain tells you "Hey, I got this from three different sources[.]" . . . But you don't realize it all traces back to the same place, and might have even reached you via bots posing as real people. If we think of this as a virus, I wouldn't know how to vaccinate for it.

Danny Westneat, UW Professor: The Information War Is Real, and We're Losing It, SeAtTLE Times (Mar. 29, 2017, 6:30 AM), https://www.seattletimes.com/seattle-news/politic 
cessed the computer of a Pentagon official: "But the attack didn't come through an email or a file buried within a seemingly innocuous document. A link, attached to a Twitter post put out by a robot account, promised a family-friendly vacation package for the summer." 32

\section{B. Judges on Social Media}

Many judges use social media. In 2012, more than 46 percent of judges surveyed for a study used a social media profile site, with Facebook being the most popular choice of over 86 percent of users. ${ }^{33}$ In 2010, a survey of state and local judges revealed approximately 40 percent of judges used social media. ${ }^{34}$ For a 2014 survey, more than 42 percent of responding court officials agreed it is necessary and only 26 percent saw it as unnecessary. ${ }^{35}$

Judges can have a substantial social media following, though significantly fewer than a popular award-winning musical artist. For example, in March 2019, Chief Judge Dillard (@JudgeDillard) had 15,000 followers on Twitter ${ }^{36}$, Justice Don Willett (@JusticeWillett) had 108,000 followers on Twitter ${ }^{37}$ and more than 19,000 followers on Facebook, ${ }^{38}$ Judge Rosemarie Aquilina

s/uw-professor-the-information-war-is-real-and-were-losing-it/ [https://perma.cc/R2LW-P6 $\mathrm{AF}]$.

32 Sheera Frenkel, Hackers Hide Cyberattacks in Social Media Posts, N.Y. TIMES (May 28, 2017), https://www.nytimes.com/2017/05/28/technology/hackers-hide-cyberattacks-in-social -media-posts.html [https://perma.cc/EHS4-CKJV].

33 New Media Comm. of the Conference of Court Pub. Info. Officers, 2012 CCPIO New Media Survey 5 (2012), http://ccpio.org/wp-content/uploads/2012/08/CCOIO-2012-N ew-Media-ReportFINAL.pdf [https://perma.cc/Y6GU-R96C].

34 New Media Comm. of the Conference of Court Pub. Info. Officers, New Media and THE COURTS 8 (2010), https://ccpio.org/wp-content/uploads/2012/06/2010-ccpio-report.pdf [https://perma.cc/S9B6-XSER].

35 Conference of Court Pub. Info. Officers, 2014 CCPIO New Media Survey 4 (2014), https://ccpio.org/wp-content/uploads/2014/08/CCPIO-New-Media-survey-report 2014.pdf [https://perma.cc/F5KF-NA7Z].

${ }^{36}$ Chief Judge Dillard (@JudgeDillard), TwiTtER, https://twitter.com/JudgeDillard [https://p erma.cc/7QHP-9Y4R] (last visited Mar. 11, 2019). As of March 11, 2019, Chief Judge Dillard was tweeting daily. Id.

37 Justice Willett (@JusticeWillett), TwITTER, https://twitter.com/JusticeWillett [https://per ma.cc/JN74-REHM] (last visited Mar. 11, 2019). As of March 11, 2019, Justice Willett's last Tweet was on January 1, 2018, which coincides with the beginning of his service on the Fifth Circuit Court of Appeals. Justice Willett (@JusticeWillett), TwITTER (Jan. 1, 2018, 5:46 PM), https://twitter.com/JusticeWillett/status/948007590130266112 [https://perma.cc/B 3DY-ZQM9]; Willett, Don R., FED. JuD. CTR., https://www.fjc.gov/history/judges/willettdon-r [https://perma.cc/BDS8-8EV4] (last visited Mar. 11, 2019). In 2015, the Texas legislature ceremonially named Judge Willett the state's "Tweeter Laureate." Kyle Swenson, Trump Wants Texas's “Tweeter Laureate" Judge on Federal Appeals Court, WASH. PosT (Sept. 29, 2017), https://www.washingtonpost.com/news/morning-mix/wp/2017/09/29/trump -wants-texass-twitter-laureate-judge-on-federal-appeals-court/ [https://perma.cc/G2DH-AW QS].

38 Justice Willett (@JusticeDonWillett),FACEBOOK, https://www.facebook.com/JusticeDon 
(@)AquiRosemarie) had more than 5,600 followers on Twitter, ${ }^{39}$ Chief Justice Elizabeth D. Walker (@bethwalkr) had more than 3,900 followers on Twitter, ${ }^{40}$ and Judge Carla Wong McMillan had more than 3,100 followers on Twitter. ${ }^{41}$ As of March 11, 2019, musical artist Beyoncé had more than 58 million followers on Facebook ${ }^{42}$ and nearly 15 million followers on Twitter. ${ }^{43}$

In her article about judges on Twitter, Professor Thornburg discussed reasons why judges use the social media platform: "In a general sense, ... for the

Willett/ [https://perma.cc/F9Z7-Q8CM] (last visited Mar. 11, 2019). As of March 11, 2019, Justice Willett's last Facebook post was on January 1, 2018. Id.

39 Judge Rosemarie Aquilina (@AquiRosemarie), TwITTER, https://witter.com/AquiRosema rie [https://perma.cc/64D8-9EVU] (last visited Mar. 11, 2019). As of March 11, 2019, Judge Aquilina was tweeting nearly every day. Id. A state judge, she serves on the 30th Circuit Court for Ingham County, Michigan. Honorable Rosemarie E. Aquilina, Ingham CTy. MicH., http://cc.ingham.org/GeneralInformation/Judges/HonorableRosemarieEAquilina.aspx [https://perma.cc/F9QD-F39P] (last visited Mar. 11, 2019). Judge Aquilina presided over the trial and sentencing of former gymnastics team doctor Larry Nasser, who was sentenced to between 40 and 175 years for sexual abuse crimes. Scott Cacciola \& Victor Mather, Larry Nassar Sentencing: "I Just Signed Your Death Warrant", N.Y. Times (Jan. 24, 2018), https://www.nytimes.com/2018/01/24/sports/larry-nassar-sentencing.html [https://perma.cc/3 6KX-GMU9]. On Twitter, she regularly expresses support for survivors of sexual abuse. @ AquiRosemarie, supra. For example, on November 30, 2018, she tweeted in response to a tweet by a user saying the user had just reported a rape from 1981, "That is amazing! So very proud of you and your voice! You are strong!’ Rosemarie Aquilina (@AquiRosemarie), TwITTER (Nov. 30, 2018, 8:05 PM), https://twitter.com/AquiRosemarie/status/10687177743 21713153 [https://perma.cc/3PQR-USP8].

40 Chief Justice Walker (@bethwalkr), TwITTER, https://twitter.com/bethwalkr [https://perm a.cc/QD9N-BFQL] (last visited Mar. 11, 2019). Justice Walker is the Chief Justice of the West Virginia Supreme Court of Appeals. Chief Justice Elizabeth D. Walker, W. VA. JUDICIARY, http://www.courtswv.gov/supreme-court/current-justices/justice-walker.html [htt ps://perma.cc/97KD-7AW3] (last visited Mar. 11, 2019). She regularly tweets on varied topics, such as gratitude or honor for various officials, being an alumnus and fan of The Ohio State University, food served at her house, or a legal writing topic. @ bethwlkr, supra. On Nov. 30. 2018, for example, she tweeted, "Thank you and RIP President George H. W. Bush 鹿.” Chief Justice Walker (@bethwalkr), TwitTER (Nov. 30, 2018, 9:19 PM), https://twitter.com/bethwalkr/status/1068736424734806016 [https://perma.cc/69ZX-TY88].

41 Judge McMillan (@JudgeCarla), TwITTER, https://twitter.com/JudgeCarla [https://perma.c c/S6NT-7P73] (last visited Mar. 11, 2019). Recently, Judge McMillan, who serves on the Georgia Court of Appeals, has tweeted about her service in the community and updates from the Georgia Court of Appeals and the Georgia Supreme Court. Id.; Carla McMillian, CourT APPEALS GA., https://www.gaappeals.us/biography/bio_judges.php?jname=Carla\%20McMill ian [https://perma.cc/2VZG-VFR7] (last visited Mar. 11, 2019). For example, on November 10, 2018, she tweeted, "Honored to preside over the semifinal round of the Thomas Tang Moot Court Competition with these judges and JAGs. Thanks to Judge Alvin T. Wong (State Court of DeKalb) who has overseen this competition for the last 15 years!" Judge McMillan (@JudgeCarla), TwitTER (Nov. 10, 2018, 2:18 PM), https://twitter.com/JudgeCarla/status/10 61382546565533697 [https://perma.cc/BJE4-79FH].

42 Beyoncé (@beyonce), FACEBOOK, https://www.facebook.com/beyonce/ [http://perma.cc/9 99Y-HR3D] (last visited Mar. 11, 2019).

43 Beyoncé (@Beyonce), TwITTER, https://twitter.com/Beyonce [https://perma.cc/E776-JFS U] (last visited Mar. 11, 2019). Tweets are rarely posted from @Beyonce. Id. A tweet was posted on June 30, 2017, and the next tweet after that was posted on June 16, 2018. Id. 
same reason everyone else does: to share news and information (personal, professional, political, commercial) and to be part of online communities discussing that information .... If a court or a judge wants to reach out to the public, social media makes sense." ${ }^{44}$ She noted, "More than $42 \%$ of public information officers agreed in 2014 that using social media is necessary for courts to connect to the public." ${ }^{45}$ Consistent with increasing transparency with the public, judges can use social media platforms like Twitter to keep the public informed about activities at their courts. ${ }^{46}$

Twitter has been used for "more interactive outreach."47 "In April of 2017, for example, the Provincial Court of British Columbia held its second annual Twitter Town Hall, using the hashtag \#AskChiefJudge to allow members of the public to ask questions. Georgia's courts have done the same using \#AskGAJudges." ${ }^{48}$

Some judges have used social media platforms for their election campaigns. ${ }^{49}$ A judge's campaign might, for example, set up a Facebook page to promote their candidacy. ${ }^{50}$ Facebook users can then elect to follow the page for campaign updates. ${ }^{51}$

Some judges have even enthusiastically advocated for judges' active use of social media. In his 2017 article, It's Time for Judges to Tweet, Like, and Share, Chief Judge Dillard of the Georgia Court of Appeals, urged his judicial peers to engage on social media. ${ }^{52}$ Judge Dillard explained that his primary goal on social media is to explain "exactly" what he does as an appellate judge in Georgia. ${ }^{53} \mathrm{He}$ discussed using social media to promote excellence in appellate practice and act as a "virtual mentor" to law students and young lawyers. ${ }^{54}$ On a recent panel, Judge Dillard remarked, "Judges are public servants. [Judges] have to be connected to the people [they] serve .... [Judges don't have] a free pass to remain cloistered ... from society. ... [N]ow is the time for judges

44 Thornburg, supra note 3 , at 256.

$45 I d$. at 257.

46 Id. at 264. ("Courts and judges also use Twitter to keep the public informed about the ongoing activities of their courts. The release of a noteworthy opinion is often announced with a tweet. Using the news media as an intermediary, judges also increase transparency and public outreach by creating virtual relationships with local news providers by following their Twitter accounts and allowing the reporters to live-tweet from the courtroom.").

${ }^{47}$ Id. at $257-58$.

48 Id. at 258.

49 graycynthia, Judicial Campaigns on Social Media, Jud. Ethics \& Discipline (July 19, 2016), https://ncscjudicialethicsblog.org/2016/07/19/1117/; see also Thornburg, supra note 3 , at 258 .

50 graycynthia, supra note 49.

51 See id.

52 Stephen Louis A. Dillard, \#Engage: It's Time for Judges to Tweet, Like, and Share, 101 JUDICATURE 11, 11-12 (2017), https://judicialstudies.duke.edu/sites/default/files/centers/judi cialstudies/judicature/judicature_101-1_dillard.pdf [https://perma.cc/3PCJ-92M3].

53 Id. at 12.

${ }^{54} \mathrm{Id}$. at 13 . 
to embrace social media[,] . . . state judges especially ...." ."55 Judge Steve Leben of the Kansas Court of Appeals tweeted approval of this conclusion by Professor Thornburg: "[I]n this day and age, when much of America gets its news from social media and those platforms are being used to delegitimize the judiciary, the third branch can ill afford to disengage. Judicial tweeting . . . should be encouraged." $" 56$

Judges who encourage social media use by other judges emphasize the positive community-building and professionalism aspects of social media engagement in an era of high political polarization. ${ }^{57}$ For example, Judge Dillard has described how professionals engage through the Twitter hashtag \#appellatetwitter and how some of them have met over Twitter and then "get together [and] have lunch." ${ }^{58} \mathrm{He}$ commented, "We talk about the vitriol on Twitter. What we don't talk about are . . the oases of sanity." 59 Judge Dillard has discussed how he uses social media to mentor and to promote civility in "divided times" when people separate themselves "into these echo chambers." 60 Judge Dillard has acknowledged the possibility of judges using poor judgment online but suggested that the "transparency" of social media might help shed light on judges who regularly engage in unethical behavior. ${ }^{61}$

\section{Extrajudicial Activities and Judicial Impartiality}

Outside of social media, judges are frequent public speakers, and the rules of ethics allow and even encourage them to engage in community activities. ${ }^{62}$ Under the Code of Conduct for federal judges, "extrajudicial activities" include

55 The Federalist Soc'y, Technology, Social Media, and Professional Ethics [NLC 2018], YouTuBe (Nov. 17, 2018), https://www.youtube.com/watch?v=rTLpBLNeb_o [https://perm a.cc/6ZZG-QWTL] (from 51:13-53:10).

56 Judge Leben (@Judge_Leben), TwitTer (Mar. 28, 2018, 9:14 AM) (alterations in original) (quoting Thornburg, supra note 3, at 249), https://twitter.com/Judge_Leben/status/97902 8940386947073 [https://perma.cc/J5FY-MSRM].

57 Chief Judge Dillard, of Georgia, and Judge Willett, of the U.S. Court of Appeals for the Fifth Circuit, have had a somewhat outsized presence on social media and have been especially vocal about the need for judges to be on social media. See supra notes $36-41$ and accompanying text. More information and views from more judges and a more diverse group of judges about judicial use of social media may reveal additional views and perspectives. This article was finalized in advance of the \#TwitterLaw Symposium planned by the Idaho Law Review for April 5, 2019; announced speakers include Justice Eva Guzman (@JusticeGuzman) of the Supreme Court of Texas and Chief Justice Bridget Mary McCormack (@BridgetMaryMc) of the Supreme Court of Michigan.

58 The Federalist Soc'y, supra note 55 (from 57:05-57:28).

59 Id. (from 57:40-57:44).

${ }^{60} I d$. (from 1:00:20-1:01:14).

${ }^{61} I d$. at (from 1:02:30-1:03:02).

${ }^{62}$ Model Code of Judicial Conduct r. 3.1 cmt. 1 (AM. Bar Ass'n 2011). This article does not focus on the activities of Justices of the Supreme Court of the United States. No judicial code of ethics applies to SCOTUS Justices, and no sitting SCOTUS Justice is on publicly available social media. Instead, this article focuses on the social media activities of other federal judges and of state judges. 
"law-related pursuits and civic, charitable, educational, religious, social, financial, fiduciary, and governmental activities." ${ }^{63}$ Judges can speak at a bar association event or teach a law school course, and many do. ${ }^{64}$ Judges frequently speak at local civic events and school commencements. For example, D.C. Circuit Court of Appeals Judge Merrick Garland gave a speech to fifth graders graduating from J.O. Wilson Elementary School in Washington, D.C. in June 2016. ${ }^{65}$ Justice Garland advised the 5th graders, "You be the brave one. Lead your friends in the right direction. Don't let them make bad choices." ${ }^{66}$ In May 2018, Chief Justice Tani G. Cantil-Sakauye of the California Supreme Court gave the keynote address at the University of California at Davis School of Law. ${ }^{67}$ She advised graduates that "the privilege" of legal education is "to spot the issues, raise the narrative, and bring change in the name of equal justice for

63 See Code of Conduct for United States Judges, 2A GuIDE TO JUDICIARY POLICY Canon 4 (Mar. 12, 2019). Canon 4 also provides that federal judges "may speak, write, lecture, and teach on both law-related and nonlegal subjects." Id.

${ }^{64}$ See, e.g., Kimberly Reich, U.S. Federal Judge, Professor Teach Course Offering UVA Law Students Insight on Judicial Decisions, U. VA. SCH. L. (Jan. 13, 2015) (describing Judicial Philosophy in Theory and Paractice course team-taught by now-Sixth Circuit Court of Appeals Judge Amul Thapar and Professor Emeritus Lillian BeVier), https://www.law.virgin ia.edu/news/2015_spr/judicial-philosophy.htm [https://perma.cc/7Y8A-48ZT] (now-Sixth Circuit Court of Appeals Judge Amul Thapar co-taught a course); Judges, U.S. CouRT APPEALS SiXTH CIRCUIT, https://www.ca6.uscourts.gov/judges (last visited Mar. 26, 2019); Annual Meeting Honorees, Speakers, Events, N.C. B. Ass'N, https://www.ncbar.org/news/an nual-meeting-honorees-and-speakers/ [https://perma.cc/VG29-LZDQ] (last visited Mar. 12, 2019) (reporting that Judge Roger L. Gregory, Chief Judge of the Fourth Circuit Court of Appeals, gave the keynote address at the North Carolina Bar Association's annual meeting in June 2017); Course Listing for William A. Fletcher, BERKELEY L., https://www.law.berkeley. edu/php-programs/courses/facultyCourses.php?pID=5561 [https://perma.cc/TY3R-VC88] (last visited Mar. 12, 2019) (explaining Ninth Circuit Court of Appeals Judge William A. Fletcher teaches Federal Courts at Berkeley Law); Event Announcement: Supreme Court Preview in San Francisco, SCOTUSBLog (Oct. 24, 2018), http://www.scotusblog.com/2018/ 10/event-announcement-supreme-court-preview-in-san-francisco/ [https://perma.cc/4YP6-Y XFQ] (sharing that Judge Marsha Berzon of the Ninth Circuit Court of Appeals spoke at a luncheon co-hosted by the Appellate Section of the Bar Association of San Francisco); Fireside Chat with Federal District Court Judge Jon Tigar, S. Asian B. Ass'N N. CAL., http://www.southasianbar.org/events/2018/11/14/fireside-chat-with-federal-district-court-

judge-jon-tigar [https://perma.cc/84ZZ-2339] (last visited Mar. 12, 2019) (stating Judge Jon Tigar of the N. District of California spoke at a South Asian Bar Association of Northern California event in November 2018); Judges Who Teach, Оніо ST. U. MoriTz C.L., https://m oritzlaw.osu.edu/faculty/judges-who-teach/ [https://perma.cc/QTU9-U22A] (last visited Mar. 11,2019 ) (listing federal and state judges slated to teach at The Ohio State University Moritz College of Law in 2013-2014 school year).

65 Nina Totenberg, Supreme Court Nominee's Advice to 5th-Graders: "Be the Brave One”, NPR (June 15, 2016, 4:28 PM), https://www.npr.org/2016/06/15/482206242/merrick-garlan d-delivers-5th-grade-commencement-address [https://perma.cc/8SNN-ENXY]. ${ }^{66} \mathrm{Id}$.

672018 Law School Keynote Speaker-Tani Cantil-Sakauye, AGGIE VIDEO, https://video.ucd avis.edu/media/2018+Law+School+Keynote+Speaker+-Tani+Cantil-Sakauye/0_gpjprww7 [https://perma.cc/XQ3P-UHK8] (last visited, Mar. 12, 2019). 
all." ${ }^{\prime 68}$ Chief Justice Maureen O'Connor of the Ohio Supreme Court gave a speech at the American Bar Association's 2018 Midyear House of Delegates Meeting. ${ }^{69}$

Judicial conduct rules recognize the value of having judges engaged in the community. A Comment to the judicial ethics rules for federal judges cautions, "Complete separation of a judge from extrajudicial activities is neither possible nor wise; a judge should not become isolated from the society in which the judge lives." 70

However, in engaging in extrajudicial activities, judges are expected to maintain impartiality and the dignity of their office. Impartiality is recognized as a fundamental and essential feature of the judicial system. ${ }^{71}$ Under the Code, a federal judge must take care to preserve the "dignity" of their office and to avoid activities that "interfere" with "official duties." 72 A federal judge should not participate in activities that "reflect adversely on the judge's impartiality" or "lead to frequent disqualification." 73

The limitations on judges' extrajudicial activities, for the sake of impartiality, extend to the financial, political, and personal. They even encompass in some respects the judge's family members. For example, a federal judge may serve as an officer, director, or employee of a business "only if the business is closely held and controlled by members of the judge's family."74 A federal judge must try to prevent any member of their family residing in the same household from soliciting or accepting a gift except to the extent that the judge

${ }^{68} I d$. (from 14:00-14:10).

${ }^{69}$ Maureen O'Connor, Chief Justice, American Bar Association 2018 Midyear House of Delegates Meeting (Feb. 5, 2018) (transcript available at the Supreme Court of Ohio Speeches Archives), https://www.supremecourt.ohio.gov/PIO/Speeches/2018/ABA.asp [http s://perma.cc/CA9N-W23J] (last visited Mar. 12, 2019). The Ohio Supreme Court maintains a publicly accessible online archive of speeches given by its justices. See, e.g., 2018 Speeches, SuP. Ст. Оhiо \& OHIO JuD. SYs., https://www.supremecourt.ohio.gov/PIO/Speeches/2018 [https://perma.cc/RP82-92S9] (last visited Mar. 11, 2019).

70 Code of Conduct for United States Judges, 2A Guide to Judiciary Policy Canon $4 \mathrm{cmt}$. (Mar. 12, 2019). The Comment continues,

[A] judge is in a unique position to contribute to the law, the legal system, and the administration of justice .... To the extent that the judge's time permits and impartiality is not compromised, the judge is encouraged to do so, either independently or through a bar association, judicial conference, or other organization dedicated to the law. Id.

71 Donald L. Burnett, Jr., A Cancer on the Republic: The Assault upon Impartiality of State Courts and the Challenge to Judicial Selection, 34 FordHAM URB. L.J. 265, 265 (2007) ("For more than two centuries, this republic has in all respects depended for its vitality upon the impartiality of an independent judiciary."). Burnett wrote, "Judicial impartiality implies judicial objectivity and resides at the core of what Justice Kennedy memorably has called the 'promise' of 'neutrality.' Impartiality is an imperative . . ." Id. at 271-72.

72 Code of Conduct for United States Judges, 2A Guide to Judiciary Policy Canon 4 (Mar. $12,2019)$.

73 Id.

74 Id. at Canon 4D(2). 
would be permitted to do so. ${ }^{75}$ And a federal judge may not endorse or oppose a candidate for public office. ${ }^{76}$

If a question of impartiality arises, a judge may have to disqualify themselves from presiding over a case. ${ }^{77}$ The Code of Judicial Conduct for federal judges and the ABA Model Rules of Judicial Conduct require a judge to disqualify themselves from a proceeding if the judge's impartiality "might reasonably be questioned." 78 The Code specifies that disqualification is required when "the judge has a personal bias or prejudice concerning a party."79

\section{BOTS AND BUBBLES}

But, in an era of bots and bubbles, have judicial ethics rules and opinions sufficiently accounted for the potential impact of these social media phenomena on impartiality? Consider the following: What if a judge on Facebook is exposed every day to a "fake news" report shared by her adult child, who received the report from a fake bot account, about the dangers of a medication, and the judge then presides over a suit brought by plaintiffs alleging they were victims of flaws in the warning labels of that medication? How can the Court determine if recusal is appropriate? Does it matter if the judge trusts her child? If the judge even recalls any details of the so-called news reports? If the judge saw images of persons' injuries from the report but cannot remember the medication name? Under what circumstances should the judge disclose the social media exposure? Should the judge recuse herself?

The answers to those questions may be different in this era of social media bots and bubbles than they were when, to receive news, people turned on the television to the nightly news or picked up the New York Times or their local city newspaper from their doorstep. Social media technology today allows for unprecedented amplification of persistent false information and speed of spreading of that information. Consumers of information and news, including judges, have never before been subject to that level of amplification and speed. Also, social media communications like retweets and likes on Twitter, unlike the instance of judges watching television or reading newspapers, are permanent and accessible forever.

75 Id.

76 See id. at Canon 5A(2); Model Code of Judicial Conduct r. 4.1(A)(3) (Am. BAR Ass'N 2011).

77 Raymond J. McKoski, Disqualifying Judges When Their Impartiality Might Reasonably Be Questioned: Moving Beyond a Failed Standard, 56 ARIZ. L. REV. 411, 429-30 (2014).

78 Code of Conduct for United States Judges, 2A Guide to Judiciary PoliCy Canon 3C(1) (Mar. 12, 2019); Model Code of Judicial Conduct r. 2.11(A) (Am. Bar Ass'N 2011); Leslie W. Abramson, Appearance of Impropriety: Deciding When a Judge's Impartiality "Might Reasonably Be Questioned", 14 Geo. J. Legal Ethics 55, 70 (2000) (noting that, on a motion to recuse, there is a presumption of partiality).

79 Code of Conduct for United States Judges, 2A Guide to Judiciary Policy Canon 3C(1)(a) (Mar. 12, 2019). 
Following is a brief overview of the technology and impact of social media bots and bubbles.

\section{A. Social Media Bots ${ }^{80}$}

"Fake accounts, deployed by governments, criminals and entrepreneurs, now infest social media networks. By some calculations, as many as 48 million of Twitter's reported active users - nearly 15 percent — are automated accounts designed to simulate real people ... "-New York Times, Jan. 27, $2018^{81}$

The word bot comes from robot. ${ }^{82}$ Social media bots are automated software programs that appear on social media and are usually not labeled as social media bots. They can easily be confused with human social media accounts. ${ }^{83}$ Bots can "interact with humans and sometimes trick them into believing they are human." ${ }^{84}$ Social media bots are "accounts controlled by software, algorithmically generating content and establishing interactions." 85 Some bots operate on Twitter all day "reading far more tweets than any human possibly could." "Some of them tweet their own messages on particular topics, sometimes mashing up tweets from other Twitter users." ${ }^{87}$ Social bots that interact with humans are increasingly appearing on social media sites like Twitter and Facebook. ${ }^{88}$ Bots are getting better at mimicking human behavior; "for example, they might be programmed to follow sleep-wake cycles to blend in with human users." $" 89$

Bots are common on social media. One study by University of Southern California and Indiana University researchers estimated that between 9 percent and 15 percent (potentially 48 million) of active Twitter accounts are bots. ${ }^{90}$

${ }^{80}$ This article does not focus on a situation where lawyers may adopt pseudonyms or false personas on social media. Instances of lawyers, directly or indirectly, adopting false personas online, have previously been explored in the ethical context. See, e.g., John G. Browning, Keep Your "Friends" Close and Your Enemies Closer: Walking the Ethical Tightrope in the Use of Social Media, 3 St. MARY's J. Legal Malpractice \& Ethics 204, 225, 228 (2013).

81 Confessore et al., supra note 1.

82 Tech Policy Lab at Univ. of Wash., What is a Bot?, YouTube (Mar. 15, 2016), https://w ww.youtube.com/watch?v=UQLo399K3PE [https://perma.cc/8SWQ-MYMC].

83 Kai Kupferschmidt, Social Media "Bots" Tried to Influence the U.S. Election. Germany May Be Next, SCI. (Sept. 13, 2017, 3:45 PM), http://www.sciencemag.org/news/2017/09/soci al-media-bots-tried-influence-us-election-germany-may-be-next [https://perma.cc/R6BA-S4 P7?type=image].

84 Tech Policy Lab at Univ. of Wash., supra note 82 (from 00:10-00:15).

${ }^{85}$ Varol et al., supra note 5, at 280.

86 Tech Policy Lab at Univ. of Wash., supra note 82 (from 01:29-01:42).

87 Id.

${ }^{88} I d$. (from 03:42-03:53).

89 Id.

90 Varol et al., supra note 5, at 280; see Zoey Chong, Up to 48 Million Twitter Accounts Are Bots, Study Says, CNET (Mar. 14, 2017, 9:05 AM), https://www.cnet.com/news/new-studysays-almost-15-percent-of-twitter-accounts-are-bots/ [https://perma.cc/ZG9A-QWYN?type= 
Bots can be divided into three categories: (1) scheduled bots that post messages based on time; (2) watcher bots that monitor other social media accounts and websites, and post when a change occurs (for example, one bot tweets information whenever the U.S. Geological Survey online posts provide new information about earthquakes in the San Francisco Bay Area); and (3) amplification bots that share and "like" posts sent by the person who has bought that bot's services. ${ }^{91}$

Bots can perform seemingly beneficial functions like sharing a poem a day, disseminating news, and coordinating volunteer activities. ${ }^{92}$ However, malicious bots have surfaced ${ }^{93}$ Human social media users' unwitting interactions with bots happen frequently, and those interactions can have consequences like the spread of "fake news" or the hacking of confidential information. ${ }^{94}$ Bots have played a role in creating fake grassroots political support, promoting terrorist propaganda and recruitment, and manipulating the stock market. ${ }^{95}$ One study of bot activity found that on most days, more than half of the tweets posted by accounts tweeting about Russian politics were produced by bots. ${ }^{96} \mathrm{Re}-$ searchers continue to study how to detect and identify bots..$^{97}$

Bots can also be relentless carriers of false information in critical areas like health. One study revealed how bots convinced consumers that using ecigarettes can help people stop their smoking habits notwithstanding that this assertion was not supported by science research. ${ }^{98}$ The lead researcher for that

image].

${ }^{91}$ Confessore, et al., supra note 1.

$92 \mathrm{Id}$.

$93 \mathrm{Id}$.

${ }^{94}$ See Burkhardt, supra note 5 ("People who are unaware that they are interacting with a bot can easily be supplied with false information. According to research published in the Communications of the Association for Computing Machinery in 2016, more than 20\% of authentic Facebook users accept friend requests indiscriminately. People with a large network of friends are more likely to accept requests from people they don't know. This can make it relatively easy for bots to infiltrate a network of social media users.") (citation omitted); Mohammad Shafahi et al., Phishing Through Social Bots on Twitter, 1 IEEE INT'L. CONF. ON Big Data (BIG DATA) 3703, 3705 (2016), https://www.computer.org/csdl/proceedings/bigdata/2016/9005/00/07841038.pdf (Phishing, although "old," remains a "serious threat").

${ }^{95}$ Varol et al., supra note 5, at 280; see also A "Dirty and Open Secret": Can Social Media Curb Fake Followers?, KNOWLEDGE@WhARTON (Feb. 2, 2018), http://knowledge.wharton.u penn.edu/article/twitter-and-the-bots/ [https://perma.cc/9XRG-R5RV].

${ }_{96}$ Denis Stukal et al., Detecting Bots on Russian Political Twitter, 5 Big DATA 310, 315 (2017).

${ }^{97}$ See Mary Ann Liebert, Inc., How Great Is the Influence and Risk of Social and Political “Bots?", PHYs.org (Dec. 19, 2017), https://phys.org/news/2017-12-great-social-politicalbots.html [https://perma.cc/L97W-8PT7].

98 Jon-Patrick Allem et al., E-Cigarette Surveillance with Social Media Data: Social Bots, Emerging Topics, and Trends, 3 JMIR PUB. HEALTH \& SURVEILLANCE 1, 6 (2017); see Robert Glatter, Bot or Not? How Fake Social Media Accounts Can Jeopardize Your Health, FORBES (Dec. 23, 2017, 10:30 AM), https://www.forbes.com/sites/robertglatter/2017/12/23/b ot-or-not-how-fake-social-media-accounts-can-jeopardize-your-health/ [https://perma.cc/5H LJ-FEQE]. 
study warned that bots spreading false health claims "are designed to promote a specific, slanted narrative - 24 hours a day, seven days a week .... Social bots can pass on health advice that hasn't been scientifically proven .... Bottom line: Online falsehoods can influence offline behavior." "99 Researchers recommend that public health campaigns be designed to counteract the impact of bots encouraging unhealthy behaviors. ${ }^{100}$

Legislators have introduced bills aimed at curbing the unwanted negative impacts of bots, including requiring social media bots to be identified as bots to social media users. ${ }^{101}$ So far, a few efforts have succeeded, most notably with California's new social media bot law and in the area of ticket sales bots. In September 2018, California adopted a law on "bots," requiring anyone using a bot online, including on a social network, to disclose that they are using a bot. ${ }^{102}$ The federal Better Online Ticket Sales Act of 2016, known as the BOTS Act, outlaws the use of bots to circumvent measures put in place to "enforce posted event ticket purchasing limits or to maintain the integrity of posted online ticket purchasing order rules[.]" 103 The stated purpose of the Act is "[t]o prohibit the circumvention of control measures used by Internet ticket sellers to ensure equitable consumer access to tickets for any given event, and for other purposes." ${ }^{104}$ As Madeline Lamo at the University of Washington wrote, bills purportedly regulating the use of bots "are designed to respond to serious, wellfounded concerns about the use of social media bots to spread misinformation and sow discord online, most infamously during the 2016 election season." 105

99 Glatter, supra note 98.

${ }^{100} \mathrm{Id}$.

101 In 2018, Senator Diane Feinstein introduced the Bot Disclosure and Accountability Act of 2018. S. 3127, 115th Cong. (2018). See Madeline Lamo, Regulating Bots on Social Media Is Easier Said Than Done, SLATE (Aug. 9, 2018, 9:07 AM), https://slate.com/technology/201 8/08/to-regulate-bots-we-have-to-define-them.html [https://perma.cc/ED27-V2WW].

102 Approved by California Governor Jerry Brown in September 2018 and operative on July 1, 2019, the new statute provides, in part,

(a) It shall be unlawful for any person to use a bot to communicate or interact with another person in California online, with the intent to mislead the other person about its artificial identity for the purpose of knowingly deceiving the person about the content of the communication in order to incentivize a purchase or sale of goods or services in a commercial transaction or to influence a vote in an election. A person using a bot shall not be liable under this section if the person discloses that it is a bot.

(b) The disclosure required by this section shall be clear, conspicuous, and reasonably designed to inform persons with whom the bot communicates or interacts that it is a bot. CAL. Bus. \& Prof. Code $§ 17941$ (West 2019).

The new code chapter defines bot as "an automated online account where all or substantially all of the actions or posts of that account are not the result of a person" and online as "appearing on any public-facing Internet Web site, Web application, or digital application, including a social network or publication." Id. § 17940.

103 BOTS Act of 2016, Pub. L. No. 114-274, 130 Stat. 1401 (2016) (codified at 15 U.S.C. $\S 45 \mathrm{c})$.

104 Id.

105 Lamo, supra note 101. 
However, as Lamo noted, attempted regulation of bots is not without definitional, technical, logistical, and constitutional complications. ${ }^{106}$

Awareness of social media bots appears to vary depending on age and education. A recent Pew research study found that younger Americans ages eighteen through forty-nine are more likely than older adults ages fifty and older to have heard about social media bots. ${ }^{107}$ The same study found that about threequarters of Americans with a college degree were aware of social media bots. ${ }^{108}$

Ultimately, bots can do a lot of good, but they can have profoundly harmful uses and impacts that are not about to be reduced in any significant way in the near future.

\section{B. Social Media Bubbles}

"(I)f people are sorting themselves into communities of like-minded types, their own freedom is at risk. They are living in a prison of their own design"Professor Cass Sunstein, on social media users ${ }^{109}$

Social media companies help people live in a customized social media world, a bubble, that accounts for their personal preferences. "Bubbles" refer to virtual information universes made by users or algorithms or both, unwittingly or not. Social media companies use algorithms to customize a social media user's experience. ${ }^{110}$ "Filter bubble," a term that was coined by Eli Pariser in 2010 , refers to the online ecosystem produced by algorithmic filtering. ${ }^{111}$ In filter bubbles, algorithms select content for a social media user's viewing according to that user's previous online behavior. ${ }^{112}$ Some have argued that filter bubbles, through their relentless personalization based on people's behavior in the

106 Id.

107 Galen Stocking \& Nami Sumida, Pew Research Ctr., Social Media Bots Draw PubliC'S ATtENTION AND CONCERN 5 (2018), http://www.journalism.org/wp-content/uploads /sites/8/2018/10/PJ_2018.10.15_social-media-bots_FINAL.pdf [https://perma.cc/3H2Q-LXZ $\mathrm{B}]$.

108 Id.

109 SunStEIN, supra note 6, at 12.

110 The Daily Dish, The Filter Bubble, ATLANTIC (Oct. 10, 2010), https://www.theatlantic.co m/daily-dish/archive/2010/10/the-filter-bubble/181427/ [https://perma.cc/ZQ2Q-7VVV]. Explaining how complex algorithms work, and the varied ways in which they can work, is beyond the scope of this article.

111 Id. (defining filter bubble); see also Elizabeth Dubois \& Grant Blank, The Echo Chamber is Overstated: The Moderating Effect of Political Interest and Diverse Media, 21 INFO., Comm. \& Soc'y 729, 731 (2018); Seth R. Flaxman et al., Filter Bubbles, Echo Chambers, and Online News Consumption, 80 Pub. Opinion Q. (Special Issue) 298, 299 (2016); Filter Bubble, MERRIAM-WEBSTER, https://www.merriam-webster.com/dictionary/filter\%20bubble [https://perma.cc/YDM7-ESLS] (last visited Mar. 13, 2019).

112 Bakshy et al., supra note 8, at 1130. 
virtual world (and beyond), exacerbate a tendency for people to select media and content that reinforce their existing preferences. ${ }^{113}$

Social media platforms give rise to the possibility of virtual echo chambers, a kind of bubble created by a social media user's own source selections, or a combination of algorithmic filtering and the user's selections. ${ }^{114}$ The use of "echo chamber" in reference to politics "is a metaphorical way to describe a situation where only certain ideas, information and beliefs are shared." 115 In an echo chamber, people will "encounter things they already agree with." 116 "Without free movement of ideas and information people inside the echo chamber will believe that this is all there is." 117 Some worry that an "echo chamber" environment could facilitate "social extremism and political polarization." 118

Still, a study conducted by Facebook in collaboration with the School of Information at the University of Michigan emphasized that, more than bubbles created by algorithms, individuals' choices determine exposure to "attitudechallenging information." 119 Those researchers, some of whom were from Facebook, concluded, "our work suggests that the power to expose oneself to perspectives from the other side in social media lies first and foremost with individuals." 120

And not everyone agrees that echo chambers are prevalent. In 2017, Dubois and Blank summarized the state of the research on the very existence of echo chambers,

113 Dubois \& Blank, supra note 111, at 731 ("The filter bubble argument suggests algorithmic filtering which personalizes content presented on social media and, through use of search engines, could exacerbate the tendency for people to select media and content which reinforce their existing preferences.") (citing PARISER, supra note 8). Interestingly, in one study of potential filter bubbles arising from algorithmic recommender systems, researchers saw "evidence that users who actually consume the items recommended to them experience lessened narrowing effects and rate items more positively." Tien T. Nguyen et al., Exploring the Filter Bubble: The Effect of Using Recommender Systems on Content Diversity, 2014 WWW PROCEEDINGS 677, http://wwwconference.org/proceedings/www2014/proceedings/p6 77.pdf.

114 Flaxman et al., supra note 111, at 299.

115 Dubois \& Blank, supra note 111, at 729 (citing to KathleEN Hall JAMIESON \& JosePH N. Cappella, Echo Chamber: Rush Limbaugh and the Conservative Media Establishment (2008) and CASS R. SunSteIn, REPUBLIC.COM 2.0 (2009)).

116 Id.

117 Id.

118 Pablo Barberá et al., Tweeting From Left to Right: Is Online Political Communication More than an Echo Chamber?, 26 PSYCHOL. SCI. 1531, 1531 (2015) ("[T]o the extent that individuals expose themselves to information that simply reinforces their existing views, greater access to information may foster selective exposure to ideologically congenial content, resulting in an 'echo chamber' environment that could facilitate social extremism and political polarization.”) (citations omitted).

119 Bakshy et al., supra note 8, at 1130.

120 Id. at 1132. 
Examinations of selective exposure have shown that individuals do tend to expose themselves to information and ideas they agree with more often but they do not tend to avoid information and ideas which are conflicting. Even among partisans in the US, the media diet of Republicans and Democrats is in fact quite similar. While some have found evidence of echo chambers on Twitter, others have shown that the trend does not persist on Facebook. ${ }^{121}$

The impact of automation and opaque algorithmic filtering on people's behaviors and beliefs is not known with a great degree of certainty. On social media, "Individuals may be exposed to information and perspectives which are also diverse or they may select varied media in a way that produces the echo chamber effect."122 Evidence "has been conflicting." 23 Some conclude that social media has played a smaller role in political polarization than had been predicted or feared during the beginning years of social media. ${ }^{124}$ Some studies have focused on the possibility that people elect to read only or mostly news that reflects their interests, opinions, and beliefs - that they live in "echo chambers" on social media. ${ }^{125}$

Cass Sunstein's prominent critique of social media customization asks that social media platforms like Facebook exercise restraint in limiting the news people see:

[I]f people are sorting themselves into communities of like-minded types, their own freedom is at risk. They are living in a prison of their own design. .

Facebook seems to think that it would be liberating if every person's News Feed could be personalized so that people see only and exactly what they want. Don't believe it. ${ }^{126}$

Sunstein describes social media customization as an "architecture of control" facilitating a situation where "birds of a feather can easily flock togeth-

121 Dubois \& Blank, supra note 111, at 730 (citations omitted).

122 Id.

123 Id.; Barberá et al., supra note 118, at 1532 ("The extent to which citizens exhibit patterns of ideological polarization in online exchanges remains an open debate. Some researchers have reported high levels of clustering along party lines, characterizing social-media platforms as echo chambers, whereas others have found that ideological segregation online is low in absolute terms - with open cross-ideological exchanges and exposure to ideological diversity being fairly common. One possible explanation for the variability in results is that some studies have relied on self-selected samples of partisan individuals, whereas others have not.") (citations omitted).

124 Dubois \& Blank, supra note 111, at 740.

125 Id. at 730; see also R. Kelly Garrett, Echo Chambers Online?: Politically Motivated Selective Exposure among Internet News Users, 14 J. COMPUTER-MEDIATED COMM. 265, 267 (2009); Shanto Iyengar \& Kyu S. Hahn, Red Media, Blue Media: Evidence of Ideological Selectivity in Media Use, 59 J. Comm. 19, 24-25 (2009).

126 Sunstein, supra note 6, at 12-16 ("In the 2016 presidential election, the News Feed spread a lot of falsehoods .... But in view of its massive role in determining what kinds of news people see, it is far from ideal if it does not include, among its core values, promoting or at least not undermining democratic self-government. Facebook can do better.”). 
er." 27 He argues, "for the sake of" "democracy itself," for an "architecture of serendipity" on social media to replace the "architecture of control":

My largest plea here ... is for an architecture of serendipity - for the sake of individual lives, group behavior, innovation, and democracy itself . . . An architecture of serendipity counteracts homophily, and promotes both selfgovernment and individual liberty. ${ }^{128}$

However, while researchers agree that social media platforms feature much polarization, the net effect on political participation and other behaviors may be less than previously feared or assumed. ${ }^{129}$ In recent research, Dubois and Blank note that "evidence-based studies of echo chambers have mostly been based on studies of political polarization in social media, especially Twitter." 130 They describe "a typical paper [that] applies network methods to data from the US to show that Democrats' and Republicans' Twitter networks are mostly separate." 131

Dubois and Blank conclude that when available diverse media, and not solely social media, are taken into account, "there is little apparent echo chamber." ${ }^{132}$ So, even if one study that looks only at Twitter finds evidence of echo chambers and political polarization, that study does not necessarily inform whether or not a given user operates in an echo chamber. That study may not have taken into account other sources that a user may access, such as in-person conversations, newspapers, and magazines. Dubois and Blank urge others to study "the entire media environment" and not solely one social media platform or solely social media. ${ }^{133}$ They conclude, "Whatever may be happening on any single social media platform, when we look at the entire media environment, there is little apparent echo chamber."134

Another group of researchers have found a higher growth in polarization among demographic groups least likely to use the internet and social media and note that their finding is inconsistent with a hypothesis that social media is a primary driver of political polarization. ${ }^{135}$ One group of researchers found that political polarization rose significantly more among the older-than-seventy-five

127 Id. at 2 .

128 Id. at 4-5.

129 Dubois \& Blank, supra note 111, at 741 ("It seems likely that networks on Twitter are polarized, as Conover et al.'s results show, and networks on other social media may be equally polarized. But social media are only part of the environment, and they are the least trusted part.") (citing M.D. Conover, Political Polarization on Twitter, 5 INT'L AAAI Conf. on Weblogs \& Social Media 89-96 (2011)).

130 Id. at 732 .

131 Id.

$132 I d$. at 740 .

133 Id.

134 Id.

135 Levi Boxell et al., Is the Internet Causing Political Polarization? Evidence from Demographics 3 (Nat'l Bureau of Econ. Research, Working Paper No. 23258, 2017), https://w ww.nber.org/papers/w23258.pdf [https://perma.cc/VTN7-2UHC]. 
demographic than for those ages eighteen through thirty-nine. ${ }^{136}$ In 2012, less than 20 percent of the over-seventy-five population used social media, while 80 percent of the eighteen through thirty-nine demographic group used social media. ${ }^{137}$

One study's authors, including Facebook researchers, claim that the Facebook platform leaves "substantial room for exposure to opposing viewpoints." 138 That study, by Facebook researchers collaborating with the School of Information at the University of Michigan, found that, on average, more than 20 percent of a Facebook user's "friends who report any ideological affiliation are from an opposing party." 139 The study's authors however do not dispute that "partisans tend to maintain relationships with like-minded contacts." 140

A recent study involving 3.8 million Twitter users concluded that "ideological segregation" on social media may have been overestimated. ${ }^{141}$ The Twitter study researchers concluded, "[t]he popularization of social media as a means of communication within interpersonal networks is not inevitably bounded by ideological contours, especially when it comes to nonpolitical issues and events." "142 In that study, researchers analyzed "big data" sources to explore the extent "to which the online media environment resembles an echo chamber characterized by selective exposure, ideological segregation, and political polarization or a 'national conversation' in which individuals of differing ideological persuasions read and retweet one another's messages." 143

The degree of "ideological segregation" could depend on topics being discussed. The researchers in the Twitter study found that discussions of the 2012 election, the 2013 government shutdown, and the 2014 State of the Union Address resembled an echo chamber. ${ }^{144}$ "Information about these events was exchanged primarily among individuals with highly similar ideological preferences." 145 They found "liberals tended to retweet tweets from other liberals, and conservatives were especially likely to retweet tweets from other conservatives." ${ }^{146}$ However, retweets about nonpolitical topics like the Boston Marathon bombing, the 2014 Super Bowl, and the 2014 Winter Olympics all crossed ideological boundaries. ${ }^{147}$ Researchers found, for example, that liberals and con-

\footnotetext{
$136 I d$.

137 Id.

138 Bakshy et al., supra note 8, at 1131.

139 Id.

140 Id.

141 Barberá et al., supra note 118, at 1532.

142 Id. at 1540.

143 Id. at 1532 .

$144 \mathrm{Id}$. at 1533.

145 Id. at 1539.

146 Id. at 1537.

${ }^{147}$ Id.
} 
servatives "interacted with each other to a considerable degree" concerning the Super Bowl. ${ }^{148}$

Timing can affect polarization. Researchers have found a pattern in social media responses to a specific event like a mass shooting at an elementary school. ${ }^{149}$ After such a tragic event, social media posts start a "national conversation," and then shift to echo chambers. ${ }^{150}$

In summary, the research on the impact of algorithmic filtering is ongoing. Some studies cited here were based on data drawn from the early years of social media, when algorithms were fewer and therefore social media users probably controlled more of what they saw and with whom they engaged. As technology evolves, the research may yet reveal greater pernicious effects of the algorithmic filtering as well as more enlightened, informed measures to combat those effects.

\section{Addressing Malicious Effects}

Social media companies only recently started stepping up efforts to filter out fake accounts, and only "after revelations that Russia-aligned hackers had deployed networks of Twitter bots to spread divisive content and junk news ...." 151 They have announced various measures to combat "malicious automation." 152 Social media researchers meanwhile have made efforts to detect bots with simple filter tools. ${ }^{153}$

Also, lawmakers have begun investigating the proliferation of automated accounts on social media platforms, and some announcements by social media companies to combat problematic accounts have followed. ${ }^{154}$ With pressure from lawmakers, journalists, and users, several social media companies have gradually acknowledged the existence of attempts to manipulate conversations

\footnotetext{
$148 I d$.

149 Id. at $1536-37$.

150 Id. at 1537 ("[W]e found that Twitter responses to some specific events-such as the tragic elementary-school shooting in Newtown, Connecticut - exhibited a dynamic shift from national conversation to echo chamber .... [T] he level of polarization increased over time, as the conversation shifted from the tragedy to a debate over gun-control policy.").

151 Confessore et al., supra note 1; see also Kate Klonick, The New Governors: The People, Rules, and Processes Governing Online Speech, 131 HarV. L. REV. 1598, 1637 (2018) (exploring how social media platforms like Facebook are moderating online speech).

152 Yoel Roth \& Del Harvey, How Twitter is Fighting Spam and Malicious Automation, TwitTER Blog (June 26, 2018), https://blog.twitter.com/official/en_us/topics/company/2018 /how-twitter-is-fighting-spam-and-malicious-automation.html [https://perma.cc/Y5J5-C79Z ]; see also Confessore et al., supra note 1 (quoting a Twitter spokesperson who said, "[w]e continue to fight hard to tackle any malicious automation on our platform as well as false or spam accounts.").

${ }^{153}$ Barberá et al., supra note 118, at 1534 ("We also applied simple activity, location, and spam filters .... to try to ensure that all Twitter users included in our analysis corresponded to actual citizens.").

${ }^{154}$ Confessore et al., supra note 1.
} 
through "[i]nauthentic accounts, spam, and malicious automation" and have announced action to combat the attempts. ${ }^{155}$ For example, Twitter announced in June 2018 that it would require new account registrants to confirm an email address or phone number when registering for Twitter. ${ }^{156}$ Twitter disclosed that it "fights spam and malicious automation" and that its "focus is increasingly on proactively identifying problematic accounts and behavior ...."157 They claimed they were focused "on developing machine learning tools that identify and take action on networks of spammy or automated accounts automatically." 158

\section{JUdicial ETHICS AND SOCIAL MEDiA}

Awareness, or at least publicity, of the ethical implications of judges as social media users is on the rise, but little has been written on the possibility of judges navigating social media amidst bots and algorithmic bubbles. ${ }^{159}$ The awareness of state and federal judges on social media about the presence of social media bots and bubbles appears not to be documented or known. ${ }^{160}$

However, much attention has been devoted to the judicial ethics of social media on several other fronts. Two successive issues of the Judicial Conduct Reporter, a publication of the National Center for State Courts Center for Judicial Ethics, were devoted to the topic of "Social media and judicial ethics."161

155 Roth \& Harvey, supra note 153; see also Confessore et al., supra note 1 (quoting a Twitter spokesperson who said, "[w]e continue to fight hard to tackle any malicious automation on our platform as well as false or spam accounts.").

156 Roth \& Harvey, supra note 153.

157 Id.

158 Id.

159 This excerpt from the Report of the Conference of Court Public Information Officers, for example, references the use of fake Twitter accounts in the specific context of pro-China tweets, thus acknowledging the presence of bots on social media but not directly linking their presence to judicial ethics:

Using social media to persuade has its risks. In an apparently state-backed effort, pro-China tweets peppered Tibetans and the surrounding region recently with at least 100 identified fake Twitter accounts, all aimed at presenting upbeat news about China and even Tibetans' "deep appreciation for China's governance of the region." But the effort was hardly veiled, as the fake account profile photos, as well as those images and videos tweeted all featured Caucasian individuals whose photos were common to Western stock-photography companies.

CONFERENCE OF COURT PUB. INFO. OfFICERS, supra note 35, at 2.

160 As mentioned earlier, a 2018 Pew research study found that older Americans ages fifty and older were less likely than younger Americans, ages eighteen to forty-nine, to be aware of social media bots. StOckING \& SUMIDA, supra note 107, at 5. While Article III judges' average age is well above fifty, the same study found that 78 percent of Americans with a college degree are aware of social media bots. Id.; Demography of Article III Judges, 17892017, FED. JUD. CTR., https://www.fjc.gov/history/exhibits/graphs-and-maps/age-and-experie nce-judges [https://perma.cc/U7ZN-R5V8] (last visited on Mar. 13, 2019).

161 See generally Gray, supra note 24; Cynthia Gray, Social Media and Judicial Ethics: Part 2, 39 JuD. CONDUCT REP. 2, 2 (2017), https://www.ncsc.org/ /media/Files/PDF/Topics/Cente r\%20for\%20Judicial\%20Ethics/JCR/JCR_Summer_2017.ashx [https://perma.cc/SFY6-RJ8 
The U.S. Judicial Conference Committee on Codes of Conduct issued an advisory opinion on judges' use of electronic media, noting:

The use of social media by judges and judicial employees raises several ethical considerations, including: (1) confidentiality; (2) avoiding impropriety in all conduct; (3) not lending the prestige of the office; (4) not detracting from the dignity of the court or reflecting adversely on the court; (5) not demonstrating special access to the court or favoritism; (6) not commenting on pending matters; (7) remaining within restrictions on fundraising; (8) not engaging in prohibited political activity; and (9) avoiding association with certain social issues that may be litigated or with organizations that frequently litigate. ${ }^{162}$

In Florida, judges can consult the Judicial Ethics Benchguide: Answers to Frequently Asked Questions. ${ }^{163}$ One of the frequently asked questions is: "May Judge, Judicial Assistant, or Judicial Candidate Participate in Social Networking Websites?"164 Facebook is listed in the Florida benchguide no fewer than eleven times. ${ }^{165}$

As mentioned earlier, the decision to disqualify a judge from a case because "impartiality might be reasonably questioned" falls to the judge herself. ${ }^{166}$ Interestingly, judges are somewhat split on whether or not they can use social media without compromising ethics. In a survey, 65 percent of judges surveyed agreed with the statement that judges can use social media without compromising ethics. ${ }^{167}$ No data was located identifying what percentage of judges on social media are aware of the presence and impact of social media bots and bubbles.

Many have explored the judicial ethics implications of judges on social media, pointing out the lack of guidance in ethical rules and urging a variety of approaches. ${ }^{168}$ Most fall on the side of current limitations being sufficient.

$\mathrm{H}]$.

162 Published Advisory Opinions, 2B Guide to Judiciary Policy $\S 220$, at 221 (Dec. 6, 2018).

163 See generally Fla. Court Educ. Council's Publ'n Comm., Judicial Ethics BENCHGUIDE: ANSWERS TO FREQUENTLY ASKED QueSTIONS (2018), http://www.flcourts.org/ core/fileparse.php/304/urlt/JudicialEthicsBenchguide.pdf.

164 Id. at 11.

165 Id. at $11-13,111$.

$166 I d$. at 167.

167 Conference of Court Pub. Info. OfFicers, supra note 35, at 27.

168 See John G. Browning, Why Can't We Be Friends? Judges' Use of Social Media, 68 U. MiAmi L. REV. 487, 533 (2014) ("Isolating judges from something viewed as so vital by much of the community is hardly desirable, as is depriving judges of technological knowledge (or at least familiarity) that can inform their handling of cases."); Craig Estlinbaum, Social Networking and Judicial Ethics, 2 ST. MARY's J. LegAl MALPRACTICE \& ETHICs 2, 28 (2012) ("The next step is for state judicial committees to draft guidance that incorporate the reality of a judiciary that is fully engaged in the Social Media Age."); M. Sue Kurita, Electronic Social Media: Friend or Foe for Judges, 7 St. MARY's J. Legal MALPRACTICE \& ETHICS 184, 184 (2017) (provides some guidance for judges' ethical use of social media); Nathanael J. Mitchell, Note, Judge 2.0: A New Approach to Judicial Ethics in the Age of Social Media, 2012 UtAH L. REv. 2127, 2158 (2012) (suggesting approaches to 
Those limitations include restrictions on ex parte communications, the obligation to act in a manner that promotes public confidence in the judiciary, and the prohibition against forming relationships that convey an impression that persons are in a position to influence the judge. All of those limitations apply to judges, whether or not they are on social media. Judges may not initiate or permit ex parte communications concerning a pending matter. ${ }^{169}$ Likewise, a lawyer "shall not ... seek to influence a judge ... by means prohibited by law" or "communicate ex parte with [a judge] . . . unless authorized . . . by court order." 170

Judicial ethics opinions have applied the requirement of judicial impartiality to judges' social media use. A judge shall act in a "manner that promotes public confidence in the independence, integrity, and impartiality of the judiciary." 171 The ABA Standing Committee on Ethics and Professional Responsibility invoked this requirement in discussing judicial ethics and social media: "For example, while sharing comments, photographs, and other information, a judge must keep in mind the requirements of Rule 1.2 that call upon the judge to act in a manner that promotes public confidence in the judiciary, as previously discussed." 172 A judge shall avoid "impropriety and the appearance of impropriety." 173 A judge shall not form relationships with persons that would convey an impression that they are in a position to influence the judge. ${ }^{174}$ The ABA Standing Committee on Ethics and Professional Responsibility, in its opinion about judges on social media, noted, "The judge should not form relationships with persons or organizations that may violate Rule $2.4(\mathrm{C})$ by conveying an impression that these persons or organizations are in a position to influence the judge." 175

Many ethics committees and state bar courts have issued stern statements reminding judges that limitations on their extrajudicial activities apply to virtual and in-real-life activities alike. ${ }^{176}$ Those limitations include impartiality. The

"ameliorate the negative effects of social media"); Shaziah Singh, Note, Friend Request Denied: Judicial Ethics and Social Media, 7 CASE W. Res. J.L. TeCh. \& InTERnet 153, 171 (2016) (provides guidance "about what constitutes an appropriate presence on social media”); Mark C. Palmer, Can Lawyers and Judges Be Social Media Friends?, AтT'Y Work (Oct. 24, 2017), https://www.attorneyatwork.com/lawyers-judges-social-media/ [http://perma .cc/8J9R-AN9K].

169 Model Code of Judicial Conduct r. 2.9(A) (Am. BAR Ass'n 2011).

170 Model Code of Prof's Conduct r. 3.5 (AM. BAR Ass'N 1983).

171 Model Code of Judicial Conduct r. 1.2 (Am. BAR Ass'n 2011).

172 ABA Comm'n on Ethics and Prof'l Responsibility, Formal Op. 462, at 2 (2013).

173 Model Code of Judicial Conduct r. 1.2 (AM. BAR Ass'n 2011).

174 Model Code of Judicial Conduct r. 2.4(C) (Am. BAR Ass'n 2011).

175 ABA Comm'n on Ethics and Prof'l Responsibility, Formal Op. 462, at 2 (2013).

176 Many ethics committees have provided guidance for lawyers on social media, but this article focuses primarily on such committees' guidance for judges on social media, except when the guidance for lawyers discusses judicial conduct. See, e.g., D.C. Bar, Ethics Opinion 371 on Social Media II: Use of Social Media in Providing Legal Services (Nov. 2016), https://www.dcbar.org/bar-resources/legal-ethics/opinions/Ethics-Opinion-371.cfm [https://p 
West Virginia code of judicial conduct includes a comment that emphasizes: "The same Rules of the Code of Judicial Conduct that govern a judicial officer's ability to socialize and communicate in person, on paper, or over the telephone also apply to the Internet and social networking sites like Facebook." ${ }^{177}$ A New Mexico judge cautioned, judges must keep in mind that the code of judicial conduct applies "with equal force to virtual actions and online comments." 178 The Preamble to the New Mexico Code of Judicial Conduct encouraged judges "to pay extra attention to issues surrounding emerging technology, including those regarding social media, and are urged to exercise extreme caution in its use so as not to violate the Code." ${ }^{179}$ In a New York state commission on judicial conduct opinion, the commission noted that rules of judicial conduct apply "in cyberspace as well as to more traditional forms of communications ..." 180

The courts' and ethics committees' approaches to judges' use of social media have been categorized as either permissive or restrictive. Restrictive approaches are described as those that forbid the use of social media entirely or forbid at least any social media contact between a judge and a lawyer who may potentially appear before the judge. ${ }^{181}$

erma.cc/FY4W-SF54] ("The ABA and several ethics opinions have opined that judges can participate in social media, and a lawyer can be a 'friend' of judges on social media sites, as long as the contacts comply with the Code of Judicial Conduct; do not undermine the judges' independence, integrity, or impartiality; and do not create an appearance of impropriety.") Also, many bar journals have provided tips for lawyers for social media behavior that are not the focus of this article. See, e.g., Melissa Lessell, Is Being Friends with a Judge on Social Media an \#Ethicsfail?, ABA (Aug. 9, 2017), https://www.americanbar.org/groups/young_la wyers/publications/tyl/topics/ethics/is_being_friends_a_judge_social_media_ethicsfail/ [https://perma.cc/8NDV-JTFQ]; Dave Stafford, Lawyer Do's and Don'ts on Social Media, IND. LAw. (Aug. 12, 2015), https://www.theindianalawyer.com/articles/37915-lawyer-dos-an d-donts-on-social-media [https://perma.cc/Q8KM-RR2J].

177 W. VA. Code of Jud. Conduct r. 3.1, cmt. 6; see also Mo. Comm'n on Ret., Removal and Discipline, Advisory Op. 186 (Apr. 24, 2015), https://www.ncsc.org/ /media/Files/PDF/ Topics/Center\%20for\%20Judicial\%20Ethics/MOAdvisoryOpinionReSocialMedia.ashx;

N.M. Advisory Comm. on the Code of Judicial Conduct, Advisory Op. Concerning Social Media (Feb. 15, 2016), available at http://jec.unm.edu/manuals-resources/advisory-opinions/ Advisory_Opinion_Social_Media.pdf; Utah Courts, Informal Advisory Op. 12-01, at 4-5 (Aug. 31, 2012), available at https://www.utcourts.gov/resources/ethadv/ethics_opinions/20 12/12-1.pdf.

178 State v. Thomas, 376 P.3d 184, 198 (N.M. 2016).

179 N.M. Code of Jud. ConduCt, r. 21-001.

180 N.Y. State Commission on Jud. Conduct, AnNual Report 2017 app. F, at 274 (2017).

181 Kurita, supra note 168, at 202-04. In an example of a restrictive approach, a Florida ethics opinion in 2009 provided that a judge may not add "friends" on social media lawyers who may appear before the judge. Fla. Sup. Ct. Judicial Ethics Advisory Comm. Op., No. 2009-20 (Nov. 17, 2009), available at http://www.jud6.org/LegalCommunity/LegalPractice/ opinions/jeacopinions/2009/2009-20.html. However, in 2018, the Florida Supreme Court held in an unpublished opinion that the allegation that "a trial judge is a Facebook 'friend" with an attorney appearing before the judge, standing alone, does not constitute a legally sufficient basis for disqualification." Law Offices of Herssein \& Herssein, P.A. v. United Servs. 
Permissive approaches allow judges to maintain a presence and contacts on social media, with the same limitations and judgment the judge is required to exercise in other community engagement beyond social media-like, commencement speeches. ${ }^{182}$ For example, the Supreme Court of Ohio's disciplinary board issued an advisory opinion in 2010 permitting social media use but with caution:

A judge may be a 'friend' on a social networking site with a lawyer who appears as counsel in a case before the judge. As with any other action a judge takes, a judge's participation on a social networking site must be done carefully in order to comply with the ethical rules in the Ohio Code of Judicial Conduct. ${ }^{183}$

The ABA Standing Committee on Ethics and Professional Responsibility issued an opinion favorably comparing judges' social media use with the use of the U.S. mail and the telephone:

Judicious use of ESM [or electronic social media] can benefit judges in both their personal and professional lives. As their use of this technology increases, judges can take advantage of its utility and potential as a valuable tool for public outreach. When used with proper care, judges' use of ESM does not necessarily compromise their duties under the Model Code any more than use of traditional and less public forms of social connection such as U.S. Mail, telephone, email or texting. ${ }^{184}$

The Committee pronounced that, because of the "open and casual nature" of social media communication, "a judge will seldom have an affirmative duty to disclose an ESM connection." 185 When a judge knows that a lawyer appearing before the judge has a social media connection to them, the Committee declared, "[t]he judge should conduct the same analysis that must be made whenever matters before the court involve persons the judge knows or has a connection with professionally or personally." 186

Judges have been reprimanded for ex parte communications and impropriety on social media. ${ }^{187}$ Behaviors that have drawn reprimand or warning include

Auto. Ass'n, No. SC17-1848, 2018 WL 5994243, at*1 (Fla. 2018); see also Jim Saunders, Judges and Lawyers Can Be Facebook 'Friends,' Florida's Top Court Decides, ORLANDO SENTINEL (Nov. 15, 2018, 6:55 PM), https://www.orlandosentinel.com/news/florida/os-ne-ju dges-lawyers-facebook-20181115-story.html [https://perma.cc/S8AK-EHLX?type=image].

182 Kurita, supra note 168 , at 204-06.

183 Sup. Ct. of Ohio, Bd. of Comm'rs on Grievances and Discipline, Op. No. 2010-7 (Dec. 3, 2010), available at $\mathrm{http} / /$ www.ohioadvop.org/wp-contents/uploads/2017/04/Op_10-007. pdf.

184 ABA Comm'n on Ethics \& Prof'1 Responsibility, Formal Op. 462, at 4 (2013).

185 Id.

186 Id.

187 Other judges, while not reprimanded by a judicial ethics body, have drawn public condemnation for social media postings. See, e.g., Emily Nitcher, Outspoken Nebraska Judge Draws Criticism for Tweets about Harassment, OMAHA WorLd-HERALD (July 27, 2018), https://www.omaha.com/news/politics/outspoken-nebraska-judge-draws-criticism-for-tweets -about-harassment/article_d3819308-625e-5b77-941d-b42d587bc7f9.html [https://perma.cc/ T5XQ-X32Z]. 
a judge exchanging sexually explicit messages on Facebook with a person who appeared before that judge in court. ${ }^{188}$ Another judge had a publicly available MySpace page which listed the judge's mood as "amorous." 189 One judge listed their interests on MySpace as: "[B]reaking my foot off in a prosecutor's ass, anything relating to the NFL, video games, sex[,] and improving my ability to break my foot off in a prosecutor's ass." 190 The North Carolina Judicial Standards Commission reprimanded a judge for "friending" a lawyer in a hearing before that judge and using a social media platform to discuss the case with the lawyer. 191 "The commission found that the ex parte communications indicated a disregard of the principles of judicial conduct and constituted conduct prejudicial to the administration of justice." 192

A recent Ninth Circuit opinion described the situation of a judge following on social media the prosecutor in a case before that judge and posting tweets related to that case: "[T]his case is a cautionary tale about the possible pitfalls of judges engaging in social media activity relating to pending cases, and we reiterate the importance of maintaining the appearance of propriety both on and off the bench." ${ }^{193}$ In June 2018, in that case, the U.S. Supreme Court declined without comment to decide whether or not the judge should have recused himself. ${ }^{194}$ The U.S. Department of Justice had argued, "A district court's 'following' such an account does not generate an appearance of bias any more than watching the office's press conferences on television or reading about the office's activities in the newspaper." 195 The DOJ shared its view that the issue "would benefit from further development in the lower courts."196

Thus, although judicial ethics standards and opinions have confirmed that the requirement of judicial impartiality extends to social media activity, they have not yet squarely addressed potential dangers to judicial impartiality posed by bots and bubbles.

\footnotetext{
188 Kurita, supra note 168 , at 223-24.

189 Id. at 224.

$190 I d$. (alterations in original).

191 See Suzanne Lever, Pssst. Hey Judge . . , 17 N.C. St. B.J. 32, 35 (2012) (citing N.C. Jud. Standards Comm., Inquiry No. 08-234 (2009)).

192 Id.

193 United States v. Sierra Pac. Indus., Inc., 862 F.3d 1157, 1175-76 (9th Cir. 2017), cert. denied, 138 S. Ct. 2675 (2018).

194 Marcia Coyle, \#Denied: US Supreme Court Won't Touch Dispute Over Tweeting Federal Judge, RECORDER (June 25, 2018, 12:34 PM), https://www.law.com/therecorder/2018/06/ 25/denied-supreme-court-wont-touch-dispute-over-tweeting-federal-judge/ [https://perma.cc/ K6XS-PYWF].

195 Brief for the United States in Opposition at 17, Sierra Pac. Indus., Inc. v. United States, 862 F.3d 1157 (No. 17-1153), 2018 WL 2357729, at*27.

196 Id. at $* 28$.
} 


\section{REDUCING RISKS TO JUDICIAL IMPARTIALITY}

Despite the persistent presence of malicious bots and social media bubbles, judges can still ethically engage on social media, with extreme caution and acute awareness of the evolving technologies. As explained below, risks that judges might fall prey to falsehoods on social media that compromise impartiality may be minimized by several factors. Also, judges should be hypervigilant and can take specific precautions. As long as bots and bubbles potentially threaten judges' ability to be independent and impartial, scholars, judges, and judicial ethics committees should continue to ask if ethical standards should be modified to account for the risks posed by bots and bubbles.

\section{A. Possibly Risk-Minimizing Forces}

\section{Low Level of Trust in Social Media as a News Source}

Although bots and bubbles exist and have enabled malicious and criminal social media use, some research suggests that the potential for social media playing a pivotal role in shaping the views of users, including judges, may be minimal. More than a billion people are on Facebook, and everyone can get news on Facebook and other leading social media platforms. However, some research suggests that relatively few people rely only on social media for news, and people do not have a high level of trust in the news they receive via social media. ${ }^{197}$ "Just $2 \%$ of individuals in the U.S. rely only on social media for news." ${ }^{198}$ Interviews with Canadians who actively discuss politics on Twitter revealed that those same Twitter users relied on "mainstream news media" and face-to-face conversations with friends when gathering information about an "important" political issue. ${ }^{199}$ People are less trusting of social media than other sources for news. ${ }^{200}$ Still, the research on social media's impact on behaviors and views is ongoing, and studies done just a few years ago may not accurately reflect current and future behaviors and feelings concerning social media.

197 Moreover, results of one survey suggest that the source of news may have some correlation to a person's level of civic participation. Dubois \& Blank, supra note 111, at 733 . From that survey, "television and magazine news consumption were found to be strongly related to increased civic participation while Internet-based news consumption was not." Id. So, even if people do read news on the Internet and on social media, any impact of that news could be reduced partially or entirely if they do not vote or otherwise engage in civic activities.

198 Id. (emphasis added).

199 Id.

200 See id. at 734; see also SMITH \& ANDERSON, supra note 21 (asserting that 3 percent of social media users in the United States indicate they have "a lot of trust" in the sites they use). 


\section{Social Media Companies' Efforts}

As discussed in Section II.C., social media companies are under pressure, especially after the 2016 election, to revisit their social media policies and practices. ${ }^{201}$ If tech companies receive sufficient pressure to rid their social media platforms of malicious bots and fake accounts, perhaps any social media user issues, including any issues judges might encounter, with "malicious bots" and fake accounts will fade away in the next few years. However, some have suggested that social media platforms like Twitter have a "business incentive against weeding out bots too aggressively."202

\section{Judges' Media Consumption}

The "media diet" of a judge may very well avoid echo chambers. More research needs to be done in this area to put judges' use of social media in the context of their other media use. One recent study found that the likelihood of an echo chamber decreased with greater media diversity and greater interest in politics: "[R]egardless of how we measure the presence of an echo chamber, greater interest in politics and more media diversity reduces the likelihood of being in an echo chamber." ${ }^{203}$ A judge with greater diversity in their "media diet" could be less likely to be subject to the potential risks of being in a social media bubble.

\section{B. Proposed Precautions}

As judges, primarily state judges and to some extent federal judges, increasingly use social media, some precautions should be implemented and questions should continue to be raised.

\section{Spot and Avoid Bots}

Judges should make a reasonable effort to use a social media platform that effectively filters out bots, or use a platform that allows users to do so easily. ${ }^{204}$ In one study involving Twitter, researchers applied filters including spam filters to try to ensure that all accounts in the study corresponded to real people. ${ }^{205}$

201 See supra Section II.C.

202 See, e.g., Confessore et al., supra note 1.

203 Dubois \& Blank, supra note 111, at 740.

204 Until social media platforms make a bot-free environment the default choice, judges would need to overcome status quo bias and confirmation bias in their social media use and choices. See, e.g., Eva Jonas et al., Confirmation Bias in Sequential Information Search After Preliminary Decisions: An Expansion of Dissonance Theoretical Research on Selective Exposure to Information, 80 J. Personality \& Soc. Psychol. 557, 557 (2001); Daniel Kahneman et al., Anomalies: The Endowment Effect, Loss Aversion, and Status Quo Bias, 5 J. ECON. PERSP. 193, 194-98 (1991); Stefan Schulz-Hardt et al., Biased Information Search in Group Decision Making, 78 J. Personality \& Soc. Psychol. 655, 655 (2000).

205 Barberá et al., supra note 118, at 1534. 
Even novice social media users can learn to spot some bots. Bots, for example, often have thousands of followers compared to just a few or no accounts being followed. ${ }^{206}$ Retweets from bot accounts can reflect a vast array of topics and languages. ${ }^{207}$

However, judges who are overworked and who sit in courts that are underfunded may not have sufficient time, training, or mental bandwidth to engage in efforts to filter out bots. Study may be needed to determine the feasibility of judges trying to spot and block bots in their social media usage.

\section{Have Diverse "Media Diets"}

As discussed in Section II.B., researchers Dubois and Blank found that those with a diverse media diet that included more than social media were more likely to encounter views and ideas different than their own. ${ }^{208}$ Even if judges encountered bubbles on social media created by themselves or by algorithms, or both, the research on social media use and ideological segregation suggests that judges can avoid possible negative effects of bubbles by reading and interacting with a diverse set of media. Thus, as mentioned earlier, research on judges' "media diets" may eventually help in determining any further steps that should be taken to curb the potential risks of social media bots and bubbles to judicial impartiality.

\section{Consider Comprehensive Approach}

State and federal judges can investigate whether approaches to social media security marketed to companies might work for the courts. Companies are advised by cybersecurity firms looking to secure clients to "take proactive measures" to safeguard their and their employees' social media accounts, just as they protect their network. ${ }^{209}$ The firms advise partnering with IT and security to take "a comprehensive approach" to address risks in the "broader social media ecosystem." 210

However, the feasibility of such investigation may hinge on court funds available for IT support and infrastructure.

206 Confessore et al., supra note 1.

207 Id. Articles abound in online media about how to spot a bot. See, e.g., Ryan Detert, Bot or Not: Seven Ways to Detect an Online Bot, ForBes (Aug. 6, 2018, 9:00 AM), https://www. forbes.com/sites/forbesagencycouncil/2018/08/06/bot-or-not-seven-ways-to-detect-an-online -bot/ [https://perma.cc/J855-JR2G].

208 See supra Section II.B.

209 See Peter Horst, The Hackers Behind the Election Meddling Are Now Coming for Your Brand, FORBES (Oct. 23, 2018, 11:41 AM), https://www.forbes.com/sites/peterhorst/2018/10 /23/the-hackers-behind-the-election-meddling-are-now-coming-for-your-brand/ [https://per ma.cc/FNY9-X3G8] (interviewing Otavio Freire, CTO and President of SafeGuardCyber). $210 I d$. 


\section{Revisit Judicial Ethics Rules Regularly}

As discussed above, although precautions can be taken and the impacts of bots and bubbles are still being researched, courts, judges, ethics committees, and scholars must regularly re-assess if the ethical rules must be adjusted to help maintain impartiality. For example, if judges' media diets and efforts to minimize bots on their social media prove to be insufficient to counteract the ills of bots and bubbles threatening judicial impartiality, judicial ethics rules should be revisited for possible modification.

A recent $\mathrm{ABA}$ ethics opinion discusses the issue of whether or not judges can use social media or the internet to find "adjudicative facts" and, in doing so, made a subtle distinction between social media and internet sites, on one hand, and books and judicial seminars, on the other. The opinion declares, no, judges cannot use social media or the internet to find "adjudicative facts," reinforcing that the court may not decide a case based on facts other than those presented on the record or in court. The opinion, however, went further and recognized that the internet is full of truth and of falsehoods, hinting perhaps that social media sites and internet sources are inherently more likely to be "biased, unreliable, or false" than books and seminars:

Social media sites provide extensive information that users share about themselves and others. Information discovered on the Internet may be highly educational and as useful to judges as judicial seminars and books. But information gathered from an Internet search may not be accurate. It may be biased, unreliable, or false. ${ }^{211}$

With further research and time to tell if the proposed precautions in this piece are feasible and effective to combat the effects of malicious or harmful social media bots and bubbles, judges, lawyers, scholars, bar associations, and judicial ethics committees may wish to re-examine if a revision to the judicial ethics rules is needed. The re-examination could begin with whether or not some instances of behavior of judges on social media should be specified as a situation in which "impartiality might be reasonably questioned" and therefore disqualification warranted.

\section{CONCLUSION}

With the presence of bots and bubbles on social media, judges on social media face a formidable threat to their ability to be impartial. Malicious bots have been the source of major security compromises and can play a key role in spreading falsehoods. Echo chambers and filter bubbles can help enhance the effects of bots. In a world where bots and bubbles' impact are just beginning to be understood and their harmful impacts just beginning to be moderated, care must be taken so that judges maintain impartiality in their decision-making. The technology of social media bots and bubbles, and knowledge about the

211 ABA Comm'n on Ethics \& Prof'1 Responsibility, Formal Op. 478, at 1 (2017). 
[Vol. 19:3

consumption of social media by judges and others, are a moving target. Judges should be ever-vigilant and take precautions to ensure impartiality amidst bots and bubbles on social media. As long as these phenomena exist on social media, scholars, judges, bar associations, and ethics committees must regularly examine if further ethical limitations and guidelines are needed. State and federal ethics committees and bar associations should take the initiative and be proactive in investigating the risks to judicial impartiality posed by social media bots and bubbles. 